\title{
エスカレーター用変速駆動メカニズムの基礎技術開発*
}

\author{
小倉学*1, 湯 村敬*2, 治田 康 雅*3 \\ 吉川達 也*4, 薮内賀 義*5

\section{Fundamental Development of Partial Speed Change Mechanism for Escalator} \\ Manabu OGURA*6 ${ }^{* 6}$ Takashi YUMURA, Yasumasa HARUTA, \\ Tatsuya YOSHIKAWA and Kazuyoshi YABUUCHI \\ ${ }^{* 6}$ Human Resources Development Center, Mitsubishi Electric Corp., \\ 8-1-1 Tsukaguchi Honmachi, Amagasaki-shi, Hyogo, 661-8661 Japan

\begin{abstract}
The conventional escalator keeps the operation speed, when passengers move at any traveling position. If the speed at the inclined middle part is faster than the riding and leaving position, such a system can not only achieve short traveling time, but can also offer safety ride to elderly and disabled person. Therefore, the concept to change the speed partially in the traveling range has a great advantage to the passenger. The idea for speed change mechanism has already been established to a moving walk, which is horizontal one dimensional motion. However there is no actual two dimensional system with the speed change mechanism, due to its complex configuration. This paper shows a new speed change mechanism for an escalator, which is a typical moving mechanism for the two dimensional service, and shows a design method of the mechanism to fill the acceleration specification. The proposed mechanism can be achieved by a simplified link and cam mechanism to realize a smooth speed change between the inclined and horizontal zone. The simplified design method based on difference equation can evaluate the transient motion of the escalator step, which is strongly affected by the geometric constraints. The simulation result and an experiment with a $5 \mathrm{~m}$-tall prototype show its design validation for the smooth ride comfort even in the area of the speed change.
\end{abstract}

Key Words : Design Engineering, Simulation, Elevator, Mechanism, Escalators, Vibration of Mechanism, Inclination Section High-Speed Escalator, Step Speed Changing, Travel Time Shortening, Safety Securing

\section{1. 腥 言}

世の中に普及しているエスカレーターは，踏段循環 路の全ての箇所で踏段が一定速度で走行するよう構成 されている. すなわち，乗降口における進行方向速度 と一定傾斜部における進行方向速度は相等しい.もし 仮に, 乗降口部の踏段速度に対し，一定僋斜部の踏段 速度を相対的に高めて駆動することができれば (以下， このような駆動メカニズムを変速駆動メカニズムと呼 ぶ), 次の 2 つの利点を持つエスカレーターが実現でき る：(1)乗降口で通常速走行, 傾斜部で高速走行するこ とで移動時間の短縮が図られる. (2)乗降口で低速走行, 一定傾斜部で通常速走行すれば，移動時間をほとんど 長くすることなく, お年寄りや体の不自由な方に対し

* 原稿受付 2009 年 5 月 28 日.

*1 正員, 三菱電機 (株) 人材開発センター(谧 661-8661 尼崎市 塚口本町 8-1-1).

*2 正員, 三菱電機 (株) 先端技術総合研究所.

*3 正員, 三菱電機 (株) 稲沢製作所 (惢 492-8682 稲沢市菱町 1 ).

${ }^{* 4}$ 三菱電機 $($ 株) 稲沢製作所.

*5 三菱電機 (株) 生産技術センター.

E-mail: Ogura.Manabu@ab.MitsubishiElectric.co.jp
乗降時の安全性が更に高められる.

これまで,このような変速駆動メカニズムは, 踏段 (パレット）間の 1 次元的な相対運動を取扱う動く歩 道においては具体的な開発例が報告されているが(1)(2), 踏段間の 2 次元的な相対運動を取り扱う必要がある工 スカレーターでは, アイデアレベルの検討 ${ }^{(3)} \sim(6) に$ とどまり，具現化例や設計法についての報告はなされ ていない.

今回, 筆者らは, 比較的単純なリンク機構と力ム機 構を併用した新機構を開発し，踏段間に隙間や干渉を 生じさせることなく，また，安全性に影響を与える振 動（加速度）を乗客が洏倒しない程度に低く抑えて滑 らかに変速させることのできる変速駆動メカニズムの 設計法を確立した. 本設計法では，連続時間で運行す る踏段の幾何学的な運動を，離散時間の応答として簡 易的に算出する方法を導出し, 変速時の加速度が仕様 值以下となる変速駆動メカニズムの形状や寸法を算出 する. そして, 階高 $5 \mathrm{~m}$ の実験機を試作し，上記技術 の妥当性を検証した. 本論文では，その内容について 
報告する.

\section{2. 变速聑动メカニスムムの構造と変速原理}

$2 \cdot 1$ 構造 踏段の速度を変化させる方法として 最も単純に考えられるのは，個々の踏段をそれぞれ 別々に速度制御する方法である. しかし，この方法で は, 踏段 1 つひとつに駆動機を取付け, 自走式 (5) とし た上に，踏段間の知間や干渉を防止するための機構や 精度の高い位置・速度制御を必要とし, 複雑で高価な ものとなる. もう一つの方法は, 機構を用いて踏段間 隔を変化させることによって踏段速度を変化させる方 法である. この方法には, 踏段間を連結するリンク機 構を, カ厶機構を用いて変態させるアイデア ${ }^{(3)}$ や, リ 一ドを変化させたねじ送り機構を用いるアイデア (6) がある. 本開発では, 単純さとコストの面で有利な, リンク機構とカム機構を用いる方法について, より単 純構成でスムーズな変速が実現できる機構を検討し， 以下に述べる変速駆動メカニズムを考案する.

図 1 に, 開発した変速駆動メカ二ズムの全体構造を 示す. また，図 2 に, 図 1 の上部拡大図を示す.さら に, 図 3, 4 に, 図2中の A 部, B 部の挔大図を示す. 踏段 (Step) は, 人が乗る踏板 (tread) と蹴上げ板 (Riser) から構成されている. 踏段の移動の案内と姿勢の制御 は, 踏段の両側面に設けられた駆動ローラ(Step link roller)が固定部に配置された駆動レール(Main track)に 案内され，同じく追従ローラ(Trailing roller)が追従レー ル(Trailing track)に案内されることにより行われる（以 上，図 2). 隣接する踏段間はリンクにより連結されて いる. この踏段間を連結するリンクは，真直ぐな 1 本 のリンクではなく, 屈折リンクと呼ぶ屈折点で 2 つに 折れ曲がることが可能な 2 本のリンクから構成されて いる (図3，4). 図5に，屈折リンクの詳細図を示す. 屈折リンクは, 隣接する踏段の駆動ローラ軸間を連結 し, 中間 (屈折点) で届折することが可能なリンク構 成となっている. 今回考案した屈折リンクは, 周折リ ンクを第 1 リンクと第 2 リンクの 2 本のリンクのみで 構成しており, リンク機構の単純化を図り, 軸受部の 数を最小化することで，ガタや摩擦の影響を極力受け 難くしている. 第 1 リンクには，くの字に曲がったブ ラケットが固定されており, ブラケットの屈曲点と屈 折リンクの屈折点 (第1リンクと第2リンクの結合部) は一致している. ブラケットの駆動ローラと反対の端 部には, 補助ローラ(Assistant roller)が取り付けられてい る. この補助ローラは補助レ一ル(Assistant track)により 案内されており, 駆動レールと補助レールの間隔を変 化させることにより, 補助ローラと補助レールは一種 のカム機構として動作し, 屈折リンクが屈伸して踏段

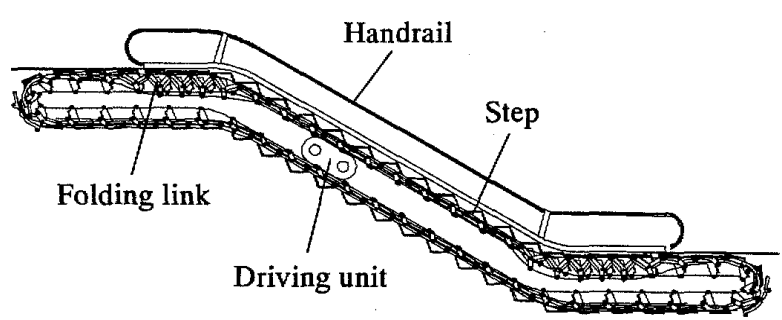

Fig.1 Variable speed driving system for escalator

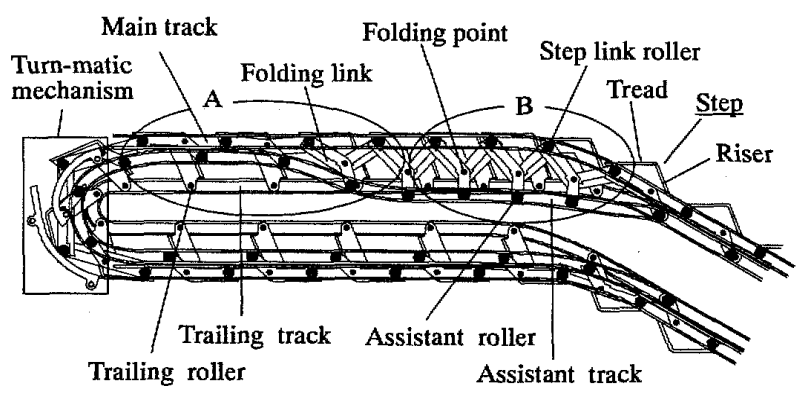

Fig.2 Magnified view of upper section of variable speed driving system for escalator

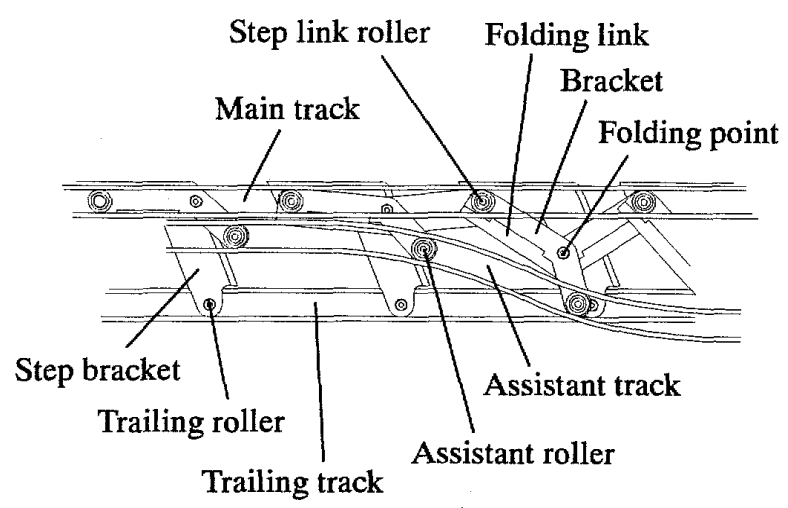

Fig.3 Magnified view of section A in fig.2

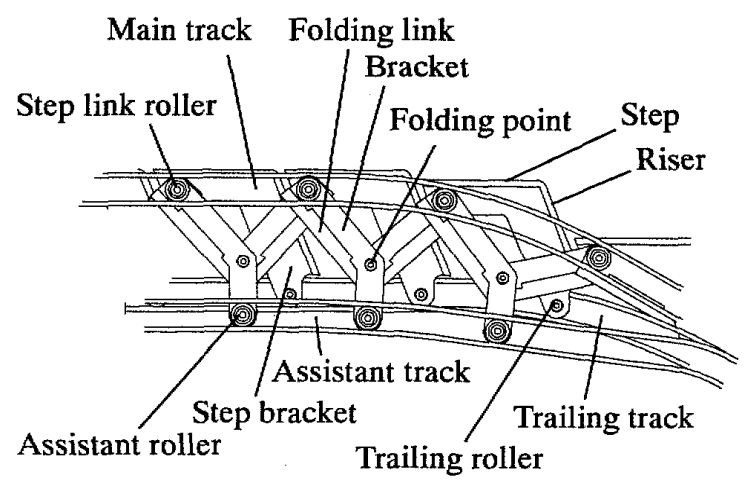

Fig.4 Magnified view of section B in fig.2 


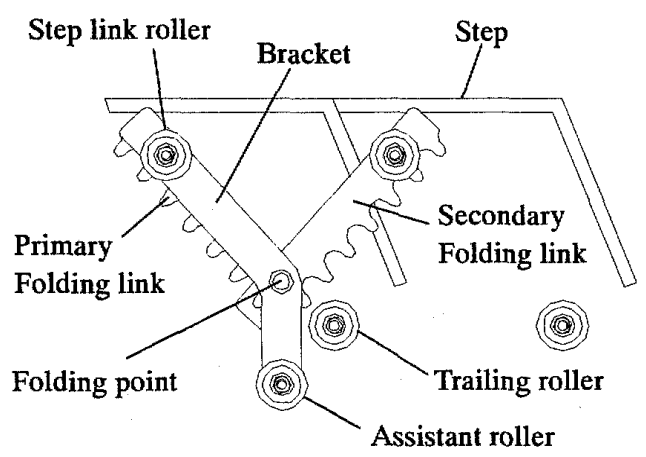

Fig.5 Folding link mechanism

間隔分変化する.

踏段の駆動は，一定傾斜部に配置された駆動装置に より行う. 図6に駆動装置部の搪大図を示す. 単純化 のため, 届折リンクに固定されているブラケットは図 示していない，駆動装置の駆動チェーンは，紙面に垂 直な方向に間隔をおいて 2 本平行に配置され，駆動ス プロケットと従動スプロケットの間に巻きかけられて いる.2 本の駆動チエーンの間には屈折リンクの歯と謎 み合うローラ（図示せす）か駆動チェーンとともに循 環移動できるよう駆動チェーンに取り付けられている. そして，屈折リンク鎖の歯が往路側，帰路側ともロー ラを介して駆動チェーンと噛み合うことにより踏段の 循環移動が可能となる。

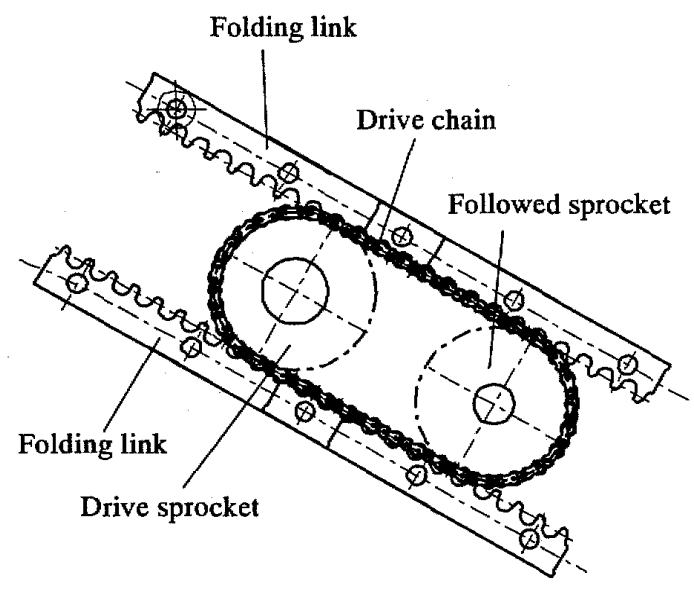

Fig.6 Magnified view of drive unit

$2 \cdot 2$ 踏段間隔之变速比 次に, 踏段間隔と変速 比（乗降口部踏段速度之一定傾斜部踏段速度の比）と の関係について考察する. 図 7 は, 乗降口部における 踏段速度 $v_{0}$, 踏段間瀜 $w$ と一定傾斜部における踏段速 度 $v_{1}$, 踏段間隔 $s$, および変速比 $k$ の関係を説明するた めの図である. 乗降口部の踏段速度を $v_{0}$, 踏段か踏段
一段分移動するために要する時間を $t$ とすると, 乗降口 部での踏段間隔 $w$ は, $w=v_{0} t$ と表される. 同様に, 一 定傾斜部における踏段速度を $v_{1}$ とすると，一定傾斜部 での踏段間隔 $s$ は, $s=v_{1} t$ となる. ここで, 変速比を $k$ とすると, $v_{1}=k v_{0}$ であるから，一定傾斜部での踏段間隔 $s$ は,

$$
s=v_{1} t=k v_{0} t=k w
$$

となる. よって, 一定傾斜部の踏段速度が乘降口部の $k$ 倍あれば，踏段間隔も $k$ 倍となる.これね逆に，一定 傾斜部の踏段間隔を乗降口部の踏段間隔の $k$ 倍にすれ ば, 変速比が $k$ となるとも言える.この関係を用いて, 以下に示す簡便な方法で変速駆動メカニズムを設計す る.

$v_{0}:$ Step speed at landing section $w$ : Step interval at landing section

$v_{1}$ : Step speed at inclination section $s$ : Step interval at inclination section

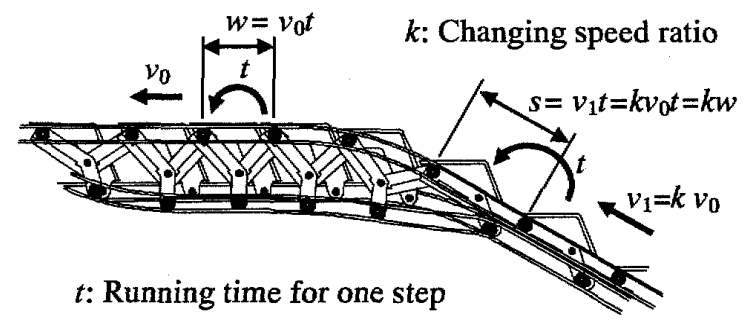

Fig.7 Concerning parameters on changing speed

\section{3. 変速沤䣦メカニスムの基本設計}

$3 \cdot 1$ 变速比 変速比は変速駆動メ力二ズムの基 本性能であり，大きくとれた方が移動時間短縮や安全 性向上の効果が大きいが, 変速比を大きくとると傾斜 部における踏段間隔が広くなり, 踏段間の段差も大き くなる. 図 8 は, これを説明する概略図である. 乗降 口における駆動口ーラ軸心間の距離が $w$ である場合, 速度の変わらない標準形のエスカレーターでは, 傾斜 部における駆動ローラ軸心間の距離も $w$ である. また,

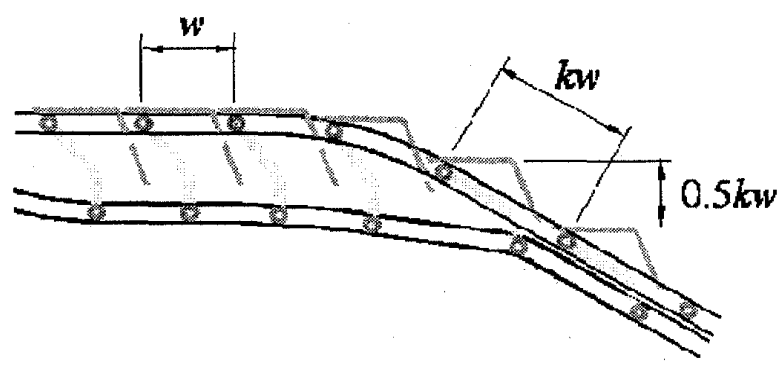

Fig.8 Relation between changing speed ratio and step position 
一般に一定傾斜部の傾斜角度は $30^{\circ}$ であるから, 踏段 間段差は $0.5 w$ となる. これに対し, 変速比が $k$ の傾斜 部高速エスカレーターでは, 傾斜部における駆動口ー 亏軸心間の距離は, $k w$ となり, 踏段間段差は $0.5 k w$ と なる. 標準形のエスカレーターでは $w$ が約 $400 \mathrm{~mm}$ で あるから，標淮形のエスカレーターの踏段間段差活約

$200 \mathrm{~mm}$ である. 今回の開発では, 変速することによ る移動時間短縮の効果とエスカレーターが非常停止し た際に乗客が踏段上を無理なく歩けることの両方を考 慮して, 変速比 $k$ を 1.5 に設定した.

$3 \cdot 2$ 踏段形状 歩行性や安全性を考慮するため, 踏段の奥行き寸法（う水平部での駆動ローラ軸心間の 距離) や踏段間の段差をざの程度の值にすべきかを検 討する必要がある. 変速比を 1.5 に設定した踏段の奥行 き寸法と踏段間段差の何通りかの組み合わせで固定踏 段を製作し，被験者に実際にその上を歩いてもらい， 歩行性や恐怖感等についての聞き取り調査を実施した. その結果, 今回の開発では, 踏段の奥行き寸法 $340 \mathrm{~mm}$, 踏段間段差255mm で設計を進めることとした. 図9は, 標潐形エスカレーターの踏段と変速駆動メカニズムに 用いる踏段の寸法関係を比較したものである.

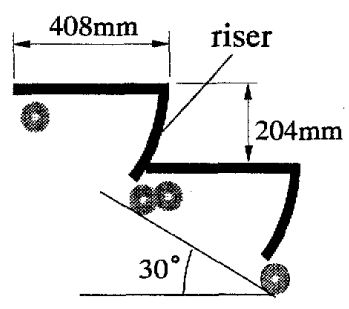

(a) Standard step

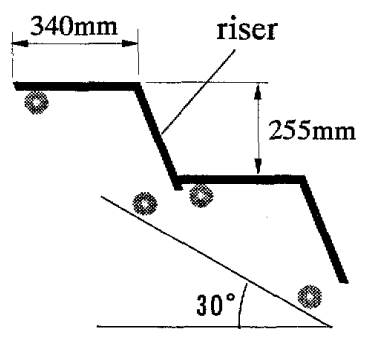

(b) Developed step
Fig.9 Comparison of shape of standard step and developed step

段差か湾化する際に生じる踏段間の開口部を，固定 されたライザー（蹴上げ板）を用いて塞ぐ場合には， ライザーの形状を，隣接踏段の相対位置関係がたどる 軌跡に一致させる必要がある. したがって，乗降口と 傾斜部との間で踏段間隔が变化しない標淮形のエスカ レーターではライザーの形状が円弧状となるが，踏段 間隔の変化する変速駆動メカニズムでは設計による自 由度がある. 今回の開発では，ライザーの製作の容易 さを考慮して，ライザーが平板状 (側面図では直線状) となるように決め，隣接踏段の相対位置関係が淔線状 に変化するように補助レールの形状を決定した. 次章 で述べる設計法の点でも，ライザーが平板状である方 が取扱いが容易である.

\section{4. 速度 ・加速度の算出と補助レール形状の設計}

図 10 に, 上曲部における届折リンク式変速駆動メ力 二ズムの幾何学的構成を示す．この図を用いて，隣接 する踏段のうち，上段側踏段の駆動ローラ軸心が一定 傾斜部之上曲部との境界にある場合を初期状態として, 上昇運転時の隣接踏段駆動口一ラ軸心の位置，進行方 向速度, 進行方向加速度を差分方程式により, 離散時 間応答として近似的に求める. 尚, 座標の原点は, 駆 動ローラ軸心移動軌跡の水平部と一定傾斜部を結ぶ半 径 $R$ の円弧（上曲部）の中心とする.

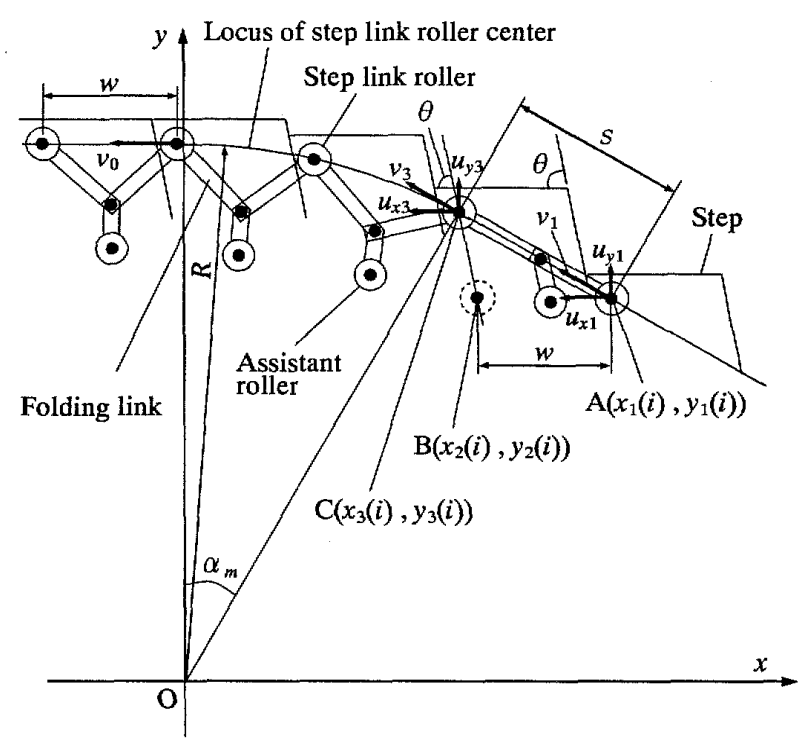

Fig.10 Composition of steps in the upper curved section

まず，上段側踏段の駆動ローラ軸心 C の初期位置 $\left(x_{3}(0), y_{3}(0)\right)$, および，下段唄踏段の駆動ローラ軸心 A の初期位置 $\left(x_{1}(0), y_{1}(0)\right)$ を求める. 一定傾斜部の傾斜角 度を $\alpha_{m}$ とすると，図 10 より，

$$
\begin{aligned}
& x_{3}(0)=R \sin \alpha_{m} \\
& y_{3}(0)=R \cos \alpha_{m}
\end{aligned}
$$

である. 式(1)の関係から， $\left(x_{1}(0), y_{1}(0)\right)$ は次式で与えら れる.

$$
\begin{aligned}
& x_{1}(0)=x_{3}(0)+s \cos \alpha_{m} \\
& y_{1}(0)=y_{3}(0)-s \sin \alpha_{m}
\end{aligned}
$$

次に, 上昇運転時の踏段の動作について検討する. 水平部での踏段進行方向の速度を $v_{0}$ とすると，一定傾 斜部での踏段進行方向の速度 $v_{1}$ は，

$$
v_{1}=k v_{0}
$$


であり,一定傾斜部における駆動口ーラ軸心間の距離 $s$ を移動するために必要な時間 $t_{a c}$ は,

$$
t_{a c}=\frac{s}{v_{1}}
$$

である. また， $t_{a c}$ を $m$ 等分（今回は $m=50$ 程度とした） した時間間隔ごとに軸心 A，C の動きを計算するもの とすれば，時間間隔 $d t$ は，

$$
d t=\frac{t_{a c}}{m}
$$

となる. 以下，時刻 $t(i)=d t \cdot i(i$ は自然数）における 軸心 $\mathrm{A}, \mathrm{C}$ の位置 $\left(x_{1}(i), y_{1}(i)\right),\left(x_{3}(i), y_{3}(i)\right)$, およひ軸心 $\mathrm{C}$ の進行方向速度 $u_{3}(i)$, 進行方向加速度 $a_{3}(i)$ を軸心 $\mathrm{A}$ が一定傾斜部上にある場合と上曲部より先にある場合 とに場合分けして求める.

軸心Aが一定傾斜部上にある場合

軸心 A の位置 $\left(x_{1}(i), y_{1}(i)\right)$ は,

$$
\begin{aligned}
& x_{1}(i)=x_{1}(0)-v_{1} t(i) \cos \alpha_{m} \\
& y_{1}(i)=y_{1}(0)+v_{1} t(i) \sin \alpha_{m}
\end{aligned}
$$

であり, 軸心 $\mathrm{A}$ の水平方向, 垂直方向の速度 $u_{x 1}(i), u_{\mathrm{y} 1}(i)$ は,

$$
\begin{aligned}
& u_{x 1}(i)=v_{1} \cos \alpha_{m} \\
& u_{y 1}(i)=v_{1} \sin \alpha_{m}
\end{aligned}
$$

である. また，軸心 A を上段側に $w$ だけ水平移動した 点 $\mathrm{B}$ の位置 $\left(x_{2}(i), y_{2}(i)\right)$ は,

$$
\begin{aligned}
& x_{2}(i)=x_{1}(i)-w \\
& y_{2}(i)=y_{1}(i)
\end{aligned}
$$

であり，水平に対するライザ一の傾きを $\theta$ とすると, 軸心 $\mathrm{C}$ の位置 $\left(x_{3}(i), y_{3}(i)\right)$ は, 点 $\mathrm{B}$ を通る傾き- $\tan \theta$ の直 線と原点を中心とする半径 $R$ の円との交点であるから,

$$
\begin{aligned}
& x_{3}(i)=\frac{f(i)-\sqrt{f(i)^{2}-\left(1+p_{1}(i)^{2}\right)\left(q_{1}(i)^{2}-R^{2}\right)}}{1+p_{1}(i)^{2}} \\
& y_{3}(i)=p_{1}(i) x_{3}(i)+q_{1}(i) \\
& \text { こご, } \\
& f(i)=-p_{1}(i) q_{1}(i) \\
& p_{1}(i)=-\tan \theta, \quad q_{1}(i)=x_{2}(i) \tan \theta+y_{2}(i)
\end{aligned}
$$

である. 尚, $\theta$ は,

$$
\theta=\tan ^{-1}\left(\frac{k \sin \alpha_{m}}{k \cos \alpha_{m}-1}\right)
$$

である.これらから, 軸心 C の水平方向, 垂直方向の 速度 $u_{23}(i), u_{33}(i)$ を踏段進行方向が正となるように(速 度が正となるように）求めると, 後退差分近似法によ り,

$$
\begin{aligned}
& u_{x 3}(i)=\frac{x_{3}(i-1)-x_{3}(i)}{d t} \\
& u_{y 3}(i)=\frac{y_{3}(i)-y_{3}(i-1)}{d t}
\end{aligned}
$$

\section{として求まる.}

軸心Aが上曲部より先にある場合（ $a_{a c}$ 経過後 $)$

時間 $t_{a c}$ 経過後, 軸心 A が上曲部より先に存在する場 合には連続の条件より, 次式が成立する.

$$
\begin{aligned}
& x_{1}(i)=x_{3}(i-m) \\
& y_{1}(i)=y_{3}(i-m)
\end{aligned}
$$

同様に, 軸心 $\mathrm{A}$ の水平方向, 垂直方向の速度 $u_{x 1}(i), u_{\mathrm{y} 1}(i)$, は,

$$
\begin{aligned}
& u_{x 1}(i)=u_{x 3}(i-m) \\
& u_{y 1}(i)=u_{y 3}(i-m)
\end{aligned}
$$

である.これらより, 点 $\mathrm{B}$, 軸心 C 位置 $\left(x_{2}(i), y_{2}(i)\right)$, $\left(x_{3}(i), y_{3}(i)\right)$ \&，式(13)，(14)，(15)，(16)から同様に求め られる. ただし， $x_{3}(i)<0$ のとき, $x_{3}(i)$ 忙点 $\mathrm{B}$ を通る傾 き- $\tan \theta$ の直線と直線 $y=R$ との交点となるから,

$$
\begin{aligned}
& x_{3}(i)=\frac{R-q_{1}(i)}{p_{1}(i)} \\
& y_{3}(i)=R
\end{aligned}
$$

である. また, 軸心 $\mathrm{C}$ の水平方向, 垂直方向の速度に ついても, 式(18), (19) から同様に求められる.

以下, 水平方向, 垂直方向の速度から, 軸心 $\mathrm{C}$ の進 行方向の速度と加速度を求める. まず, 速度について 法, 水平方向速度と垂直方向速度の単純なベクトル和 となるから, 軘心 C の進行方向速度 $u_{3}(i)$ は，

$$
u_{3}(i)=\sqrt{u_{x 3}(i)^{2}+u_{y 3}(i)^{2}}
$$

となる. また, 進行方向加速度 $a(i)$ は, 速度から, 直ち に,

$$
a(i)=\frac{u_{3}(i)-u_{3}(i-1)}{d t}
$$

として求めることができる.

加速度が $500 \mathrm{~mm} / \mathrm{s}^{2}$ 以下であれば, 乗客が転倒する可 能性は低いことから（安全性を十分確保するため, 更 に小さな值で規格化しようとする動きもあるが), 今回 の開発では, この值を目標仕様として, 設計を進めた. 
図 11, 12 は, $R=1610 \mathrm{~mm}, w=340 \mathrm{~mm}, \alpha_{m}=30^{\circ}$ とし $\tau, v_{0}=500 \mathrm{~mm} / \mathrm{s}, \quad v_{1}=750 \mathrm{~mm} / \mathrm{s}$ の場合と $v_{0}=333 \mathrm{~mm} / \mathrm{s}$, $v_{1}=500 \mathrm{~mm} / \mathrm{s}$ の場合（標淮のエスカレーターの進行方向 速度は $500 \mathrm{~mm} / \mathrm{s}$ ）の上曲部上昇運転時における軸心 $\mathrm{C}$ の進行方向速度およひ進行方向加速度の変化を示すも のである. 尚, 今回, エスカレーターの傾斜角度を $30^{\circ}$ としているのは, 前章で検討した歩行安全性, 恐怖感 とエスカレーターの設置スペースの両方を考慮した結 果による. また，曲部の曲率半径 $R$ を $1610 \mathrm{~mm}$ とした のは，曲率半径はできるだけ小さくした方が移動時間 を短縮できるが，変速時の最大加速度は大きくなるた め, 最大加速度の目標值である $500 \mathrm{~mm} / \mathrm{s}^{2}$ 以下に $10 \%$ 程 度の余裕をみて決定したものである.これは，図12の $750 \rightarrow 500 \mathrm{~mm} / \mathrm{s}$ 変速時のグラフで, 最大加速度 (減速度) が約 $-450 \mathrm{~mm} / \mathrm{s}^{2}(=-500 \times 0.9)$ になっていることに対応す る.

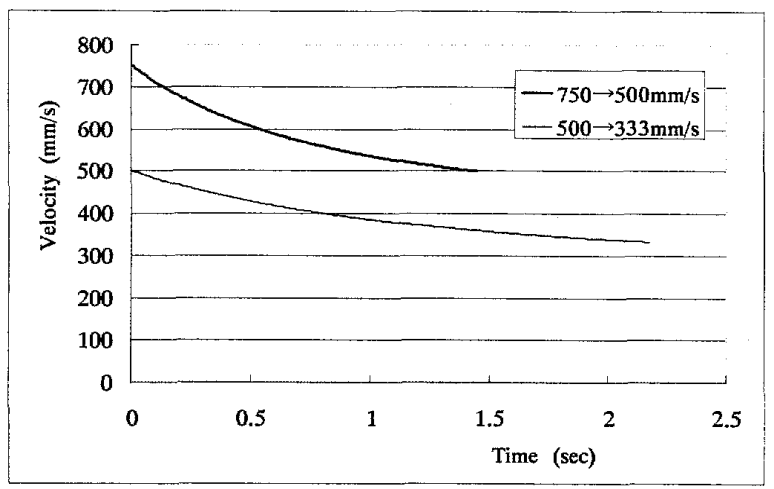

Fig.11 Step velocity in upper curved section during upward motion

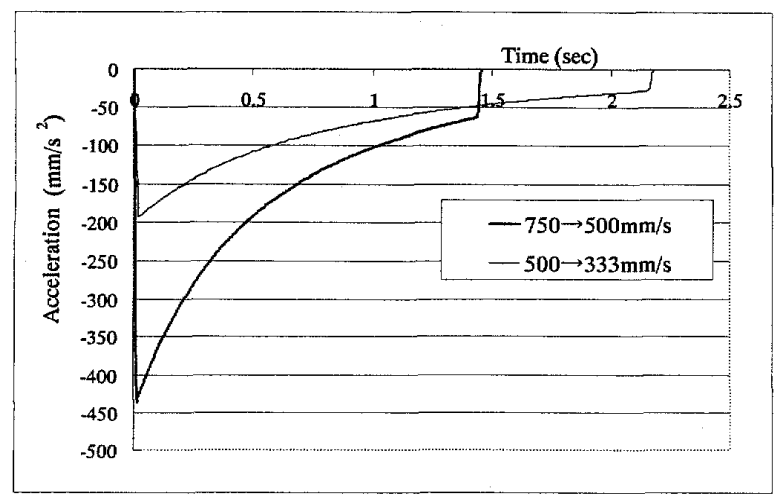

Fig.12 Step acceleration in upper curved section during upward motion

これらの図から, ライザー形状が直線的であっても, 上曲部 (変速領域)において速度は滑らかに減速する
ことがわかる. また，加速度（減速度）は，一定傾斜 部から上曲部に進入する箇所で最も大きくなっている が，先にも述べたように，750 $\mathrm{mm} / \mathrm{s}$ から $500 \mathrm{~mm} / \mathrm{s} へ の$ 変速の場合でも目標值である $500 \mathrm{~mm} / \mathrm{s}^{2}$ 以下となってい る.

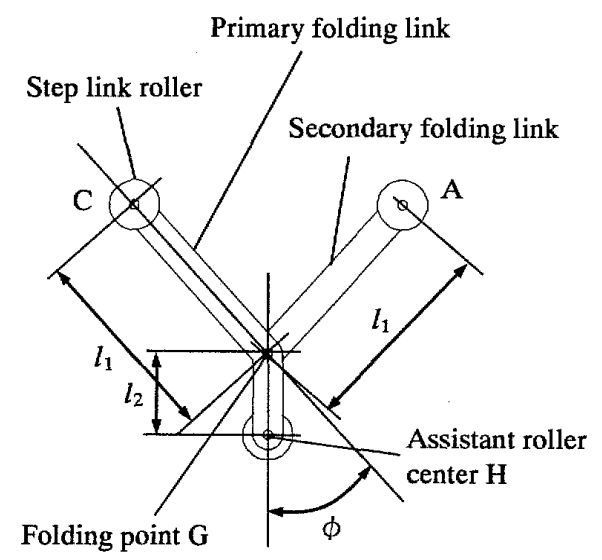

Fig.13 Shape of folding link

以上の検討により, 変速領域における進行方向速度, および，加速度の評価が可能となったが，これが実現 されるように補助レールの形状を決定する必要がある. ここでは, 図 13 を用いて, 補助レール形状の決定方法 を簡単に説明する. 今回の設計では, 第 1 リンクの駆 動ローラ軸心から屈折点までの距離と第 2 リンクの長 さを等しく $l_{1}(=255 \mathrm{~mm}$ : 一定傾斜部における踏段間隔 $510 \mathrm{~mm}$ の 1/2) として検討を進めた。隣接する踏段の 駆動ローラ軸心の位置 A，C が決定されると届折点 $\mathrm{G}$ の位置は，軸心 A を中心とする半径 $l_{1}$ の円と軸心 C を 中心とする半径 $l_{1}$ の円の交点として求められる. 補助 ロ一ラ軸心 $\mathrm{H}$ は，屈折点 $\mathrm{G}$ を起点に直線 CG から角度 $\phi た ゙ け$ 折り曲げた直線上の屈折点 $\mathrm{G}$ から $l_{2}$ の距離にあ

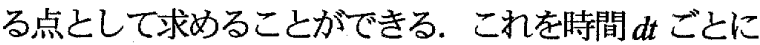
算出していくと, 補助口ーラ軸心 $\mathrm{H}$ の移動軌跡を求め ることができる. 補助レールの形状は，この補助ロー ラ軸心 $\mathrm{H}$ の軌跡から補助ローラの半径分だけ離れた平 行線を引くことにより決定される. 尚, $l_{2}$ の長さは, 一 定傾斜部で駆動ローラ軸と補助レールが干渉しない範 囲で最も短い長さにとっている.

\section{5. 試 作}

エスカレーターの変速駆動メカニズムは, リンク機 構や力ム機構（ローラとレ一ルの当接部）を多用して おり，摩擦やガ夕の影響が出易い構造となっている。 摩擦やガ夕の影響は計算では予測しにくく，それらが 動作特性にどの程度影響するのかを明らかにするため 
には，実験的な検討が必要となる．また，前章までの 検討で, 原理的には実現可能との見通しが得られたが， 実際に具現化が可能であるのかどうかを実験的に確認 しておく必要がある. 表 1 は, 確認実験のために製作 した実験機の主な仕様である. また，図 14 は，実験機 の下曲部から下側乗降口部にかけてのレール, 図15は,

Table 1 Specification of prototype

\begin{tabular}{|l|l|}
\hline Height & $5000 \mathrm{~mm}$ \\
\hline Horizontal length & $18260 \mathrm{~mm}$ \\
\hline Depth of step: $\mathrm{w}$ & $340 \mathrm{~mm}$ \\
\hline Height of step & $255 \mathrm{~mm}$ \\
\hline Inclination angle: $\alpha_{m}$ & $30^{\circ}$ \\
\hline Velocity of inclination section & $750 \mathrm{~mm} / \mathrm{sec}$ \\
\hline Number of steps & 66 \\
\hline Changing speed ratio: $k$ & 1.5 \\
\hline
\end{tabular}

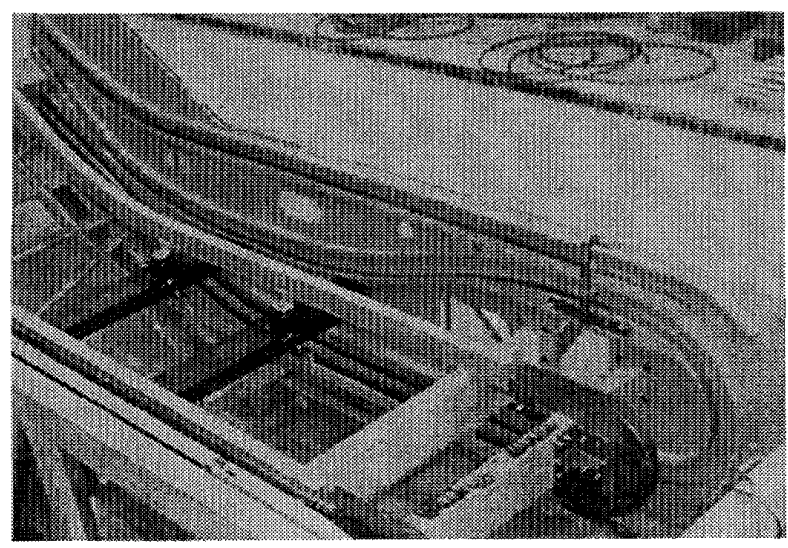

Fig.14 Rail of prototype from lower curved rail section to lower landing section

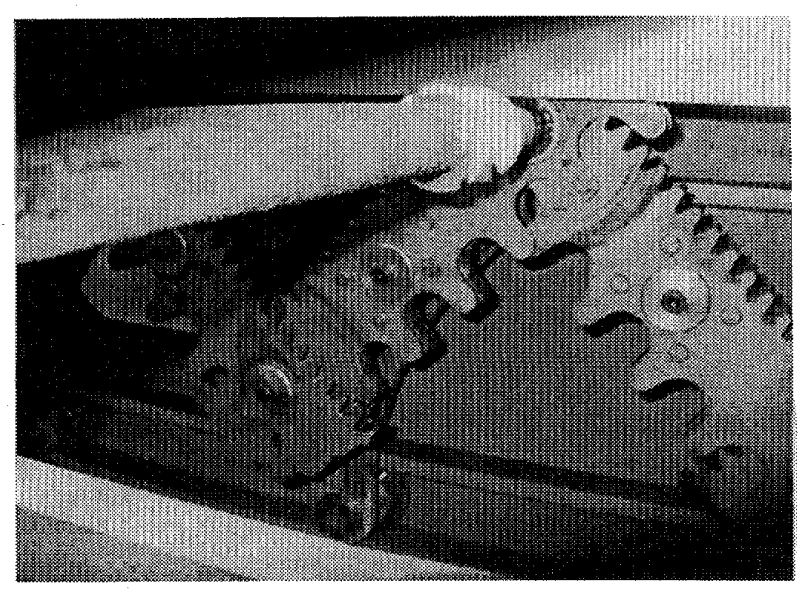

Fig.15 Folding link mechanism of prototype at lower landing section
実験機の水平部における届折リンク機構である.

本実験機では，製作の容易化を図るため，変速領域 における補助レールの形状を複数個の円弧と直線で近 似している. 近似に際しては, 円弧と円弧, あるいは, 円弧と直線の境界部分の傾きが滑らかに繫がるように, 円弧の中心や半径，直線の傾きを決定した． また，近 似曲線の理想曲線からのずれ量は，曲部にお汭る隣接 踏段の相対位置関係がほぼ直線的に（ライザーをなぞ るように）変化する範用に抑えた. 図 16 は，上曲部に おける補助口ーラ軸心の移動軌跡の理想曲線と近似曲 線を比較したものであり，両者がほぼ完全に一致して いることがわかる. 一定傾斜部側 (右端) で理想曲線 と近似曲線が一致していないのは, 理想曲線はエスカ レーターの曲部と一定傾斜部の間で傾きが不連続とな るが，近似曲線ではこれを $R$ で補間しているためであ る.

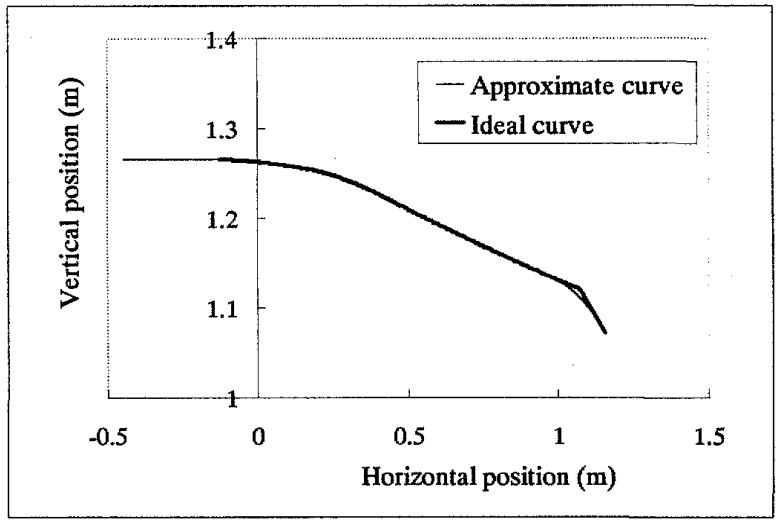

Fig.16 Comparison of approximate curve and ideal curve for moving locus of assistant roller

今回開発した速度, 加速度の簡易計算手法 (差分近 似法）の妥当性を検証するため, 試作したレール形状 での速度, 加速度を簡易計算手法, 沉用の機構解析り フトである「DADS」(現 Virtual.Lab Motion) による詳 細シミュレーション，および，実測の間で比較した。 DADS による詳細シミュレーションを実施したのは実 駼機の試作前に簡易計算には現れない動作特性の有無 を確認するためである. 速度については, 簡易計算手 法と実測結果の比較のみを示す (図 17) が, 両者の速 度はよく一致していることがわかる. 図 18,19 は加速 度の比較であり，それぞれ，簡易計算手法と DADS, DADS と実測の間のものである. 簡易計算とDADS に よる詳細シミュレーションの加速度の比較 (図 18) で は, 詳細シミュレーションの $23.65 \mathrm{~s}, 24.2 \mathrm{~s}$ 付近にみら 
れる大きな加速度変動以外の部分についてはよく一致 していると言える.この大きな加速度変動は簡易計算 モデルでは考慮していないターンマチック機構（図 2 の左端の2つの円弧状のレールが組み合わされた機構) の動作に起因するものである. しかし, 実測結果から

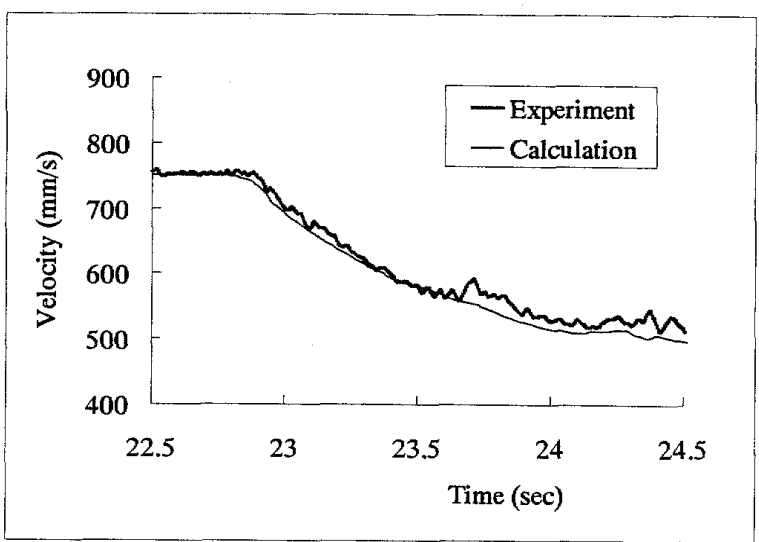

Fig.17 Comparison between experiment and calculation of velocity of full-scale model

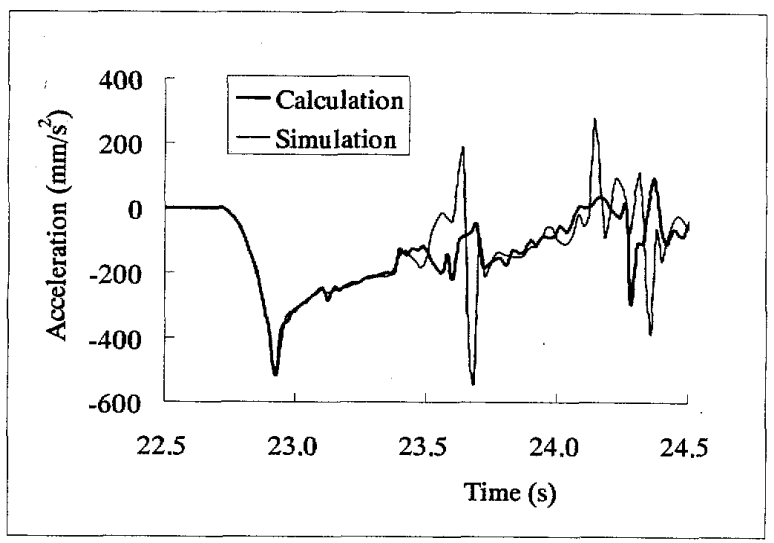

Fig.18 Comparison between calculation and simulation of acceleration of full-scale model

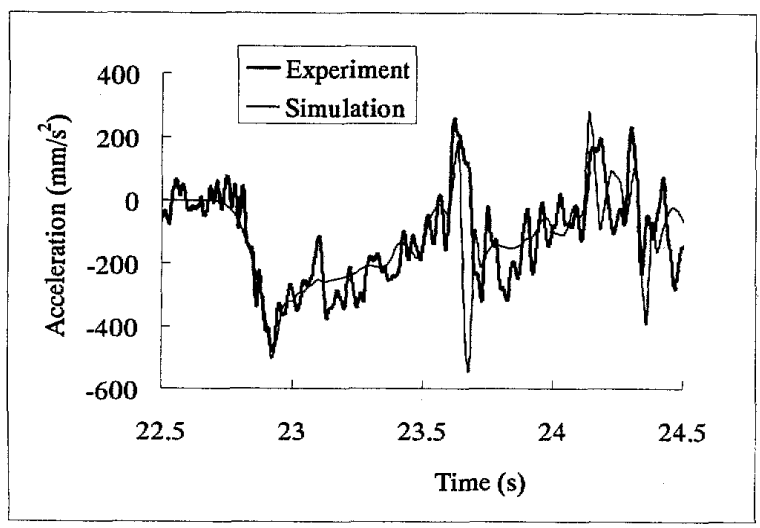

Fig.19 Comparison between experiment and simulation of acceleration of full-scale model
わかるようにこの加速度変動は目標値としていた士 $500 \mathrm{~mm} / \mathrm{s}^{2}$ 以内に入っており，安全性に影響を与えるも のではない，このターンマチック機構に起因する加速 度変動を除けば，簡易計算手法により, 補助レール形 状に起因する加速度変動を精度よく算出できるここが 確認できる．また，図 19 では，実測結果と詳細シミュ レーションの結果がよく一致することが確認できる.

さらに, これらの加速度特性は, 図 $12(750 \rightarrow 500 \mathrm{~mm} / \mathrm{s})$ ともよく一致している. ただ, 実験機では補助レ一ル 形状が理想曲線ではないことや一定傾斜部と上曲部の 境界部でレールの傾きが不連続とならないよう $R$ で補 間していることにより，両者には若干の違いが生じて いる.

以上より，本設計法およびレール形状の近似方法が 補助レールの設計に有効であることが確認できた.

\section{6. 結 言}

本論文では, 2 次元的な動作を行うエスカレーターで の変速駆動メカニズムの開発を目的に, 具現化可能な 機構の考案とその設計法の検討を行い，以下の結論を 得た.

(1) 比較的単純なリンク機構とカム機構を併用した具 現化可能な変速駆動メカニズムを考案した.

(2) エスカレーターの使用状況に基づき, 有効な変速比, 踏段間隔，踏段形状を決定した.

(3) 変速領域における補助レ一ルの設計法を確立し, 変 速時の加速度を算出する式を導出した. また, この 加速度を, 乗客が転倒する可能性の低い $500 \mathrm{~mm} / \mathrm{s}^{2}$ 以下に抑制可能な機構およびレール形状と寸法を 明らかにした。

（4）これらの設計結果を基に，実験機を試作し，本設計 法の妥当性を確認した.

\section{文献}

(1) Tadachi,K, Variable speed moving walk "Accel Liner"(in Japanese), Journal of the Japan Society of Mechanical Engineers, Vol.104,No.992,(2001.7),p49

(2) Saeki,H. Nuwa,T. Yasukawa,M. Takagi,S. Takasaki,K, SPEED WALK:Development of Accelerating Moving Walk,Mitsubishi-Jukogihou, Vo1.32,No.4,(1995.7),pp260 $-263$

(3) Nakazawa,H., Variable speed escalator(in Japanese), Japanese Patent Disclosure, JP, S51-112087, A(1976)

(4) Nakatani,H., Middle section high-speed escalator(in Japanese), Japanese Patent Disclosure, JP, H03-211186, A(1991) 
(5) Tanigawa,J. Yokoyama,H., Escalator that has step with driving device(in Japanese), Japanese Patent Disclosure, JP, 2001-163562, A(2001)

(6) Takasaki, Variable speed escalator(in Japanese), Japanese Patent Disclosure, JP, S56-113676, A(1981) 